\title{
ПРОСУВАННЯ ТОВАРІВ МЕДИЧНОГО ПРИЗНАЧЕННЯ У СОЦІАЛЬНИХ МЕРЕЖАХ
}

\section{THE ROLE OF SOCIAL NETWORK MARKETING IN THE PROMOTION OF MEDICAL GOODS}

\author{
Куваєва Тетяна Володимирівна \\ кандидат економічних наук, доцент, \\ Національний технічний університет «Дніпровська політехніка» \\ ORCID: https://orcid.org/0000-0002-8796-3189 \\ Баржак Єва Дмитрівна \\ студентка, \\ Національний технічний університет «Дніпровська політехніка» \\ ORCID: https://orcid.org/0000-0001-9042-7590 \\ Kuvaieva Tetiana, Barzhak Yeva \\ Dnipro University of Technology
}

\begin{abstract}
Метою дослідження є визначення особливостей просування товарів медичного призначення у соціальних мережах. Актуальність теми полягає в тому, що нехтування умовами сучасного ринку, такими як використання маркетингу у соціальних мережах, може призводити до низького рівня впізнаваності серед цільової аудиторії. Враховуючи те, що соціальні мережі стали невід'ємною частиною бізнесу, не можна недооцінювати їхній вплив на вибір споживача. Методика досліджень передбачає аналіз досвіду просування у соціальних мережах всесвітніх медичних брендів. Виявлено, що просування медичних товарів у соціальних мережах має свої особливості та відрізняється від просування товарів продуктового та господарського призначення. Встановлено, що просування товарів такого вузького спектра, як медичний, дозволяє компанії охопити свою цільову аудиторію і підвищити рівень продажів.
\end{abstract}

Ключові слова: маркетинг у соціальних мережах, товари медичного призначення, просування.

Целью исследования является определение особенностей продвижения товаров медицинского назначения в социальных сетях. Актуальность темы заключается в том, что пренебрежение условиями современного рынка, такими как использование маркетинга в социальных сетях, может приводить к низкому узнаваемости среди целевой аудитории. Учитывая, что социальные сети стали неотъемлемой частью бизнеса, нельзя недооценивать их влияние на выбор потребителя. Методика исследований предполагает анализ опыта продвижения в социальных сетях всемирных медицинских брендов. Установлено, что продвижение медицинских товаров в социальных сетях имеет свои особенности и отличается от продвижения товаров продуктового и хозяйственного назначения. Установлено, что продвижение товаров такого узкого спектра как медицинский позволяет компании охватить свою целевую аудиторию и повысить уровень продаж.

Ключевые слова: маркетинг в социальных сетях, товары медицинского назначения, продвижение.

The article is devoted to determine the features of the promotion of medical products in social networks. The relevance of the topic is that neglecting the conditions of the modern market, such as the use of marketing in social networks, can lead to low recognition among the target audience. Given that social media has become an integral part of business, its impact on consumer choice should not be underestimated. The research methodology involves analyzing the experience of promoting global medical brands in social networks. It was found that the promotion of medical products in social networks has its own characteristics and differs from the promotion of grocery and household goods. It is established that the promotion of such a narrow spectrum as medical products allows the company to reach its target audience and increase the level of sales. It is concluded that social media are appropriate due to their low cost, viral coverage, ease of use and accessibility. Digital technologies are constantly becoming more accessible, which contributes to the constant growth of Internet and social network users. People turn to social media as a way to connect with each other, build communities and seek information. As social media becomes an integral part of people's lives, it will also be important for the growth and promotion of medical products. It is highlighted that the technology of social platforms, focusing on user-generated content and a culture of participation, continues to evolve. As a result, 
not only the way people interact with each other changes, but also the way companies interact with their customers. The most important of these changes is to increase the use of social networks. Users spend more time on social networks after the start of quarantine restrictions to compensate for the lack of live communication. It is determined that advertising on Facebook and Instagram temporarily prohibit for certain medical and other high-demand products related to COVID-19. Such goods include medical face masks, including masks used by health professionals to protect against various diseases, COVID-19 diagnostic test systems self-diagnostic products etc.

Keywords: social media marketing, medical products, promotion.

Постановка проблеми. За останні два роки однією 3 найбільш затребуваних тематик у соціальних мережах є проблеми у ссрері охорони здоров'я. Провайдери, агентства та бренди повинні створювати привабливий соціальний контент. Цей вміст має бути інфрормативним, своєчасним і точним. При цьому необхідно дотримуватися всіх відповідних правил і норм. Численні дослідження доводять, що сучасні споживачі використовували соціальні мережі «хоча б один раз», щоб дізнатися про COVID-19. У той же час значна частка клієнтів зазначила, що навряд чи будуть перевіряти інорормацію, яку знайшла в соціальних мережах, у медичних працівників.

Соціальні медіа стали способом для людей взаємодіяти та обмінюватися інформацією в режимі реального часу, стимулюючи розвиток медицини та сприяючи відносинам між усіма зацікавленими сторонами системи охорони здоров'я. Так очікується, що успіх виробників товарів медичного призначення буде залежати від здатності компанії використовувати можливості, які вона пропонує. До таких товарів можна віднести бинти, вату, марлеві серветки, рукавички, пластирі, шприци та засоби для проведення операцій, маніпуляцій, надання першої допомоги та догляду за пацієнтами. Однією із головних причин, що приводить до необхідності просування товарів у соціальних мережах - це присутність цільової аудиторії.

Аналіз останніх досліджень і публікацій. Сьогодні технологія соціальних платформ, що робить акцент на контенті, створеному користувачами, і культурі участі, продовжує активно розвиватися [1]. В результаті цього змінюється не тільки спосіб взаємодії людей один з одним, а й компаній з їхніми клієнтами. Найважливішою 3 цих змін $\epsilon$ збільшення використання соціальних мереж. Користувачі витрачають більше часу на соціальні мережі після початку карантинних обмежень з метою компенсації браку живого спілкування. За результатами опитування GlobalWeblndex, $42 \%$ користувачів тепер проводять більше часу в соціальних мережах, ніж до пандемії. Небагато користувачів повністю усвідомлю- ють, як соціальні мережі сформували їхнє життя. За своєю суттю соціальні медіа, як і традиційні аналоги (наприклад, газети) «призначені для запису, категоризації, зберігання та ранжування життєвого досвіду» [2]. Соціальні медіа все частіше фрормують соціальне життя, а також забезпечують призму, через яку можна його переглядати.

Важливо те, що соціальні медіа $€$ як текстовими, так і візуальними, завдяки можливості людей документувати та публікувати свій соціальний досвід через слова та зображення. Соціальні медіа були визначені як перспективне джерело для розуміння соціальних і культурних дискурсів [3], що призвело до різкого зростання наукового інтересу. Наприклад, проведені дослідження виявили, що щорічна кількість наукових суспільних статей 3 даними соціальних мереж зросла за останні десять років у 5 разів. Переважна більшість наукових робіт присвячена сама вивченню впливу текстових матеріали на розуміння соціальних проблем. На відміну від своїх текстових аналогів в аналізі соціальних мереж, зображенням присвячена незначна кількість досліджень. Метадані зображень - такі як геотеги, назви зображень та короткі описи - використовуються частіше, ніж фрактичний вміст фротографрій.

У той же час нерозкритим залишається питання використання соціальних мереж на В2В ринку та при просуванні товарів особливого попиту. Тому доцільним $€$ дослідити особливості просування товарів особливого призначення у соціальних мережах.

Формулювання цілей статті (постановка завдання). Проаналізувати особливості просування товарів медичного призначення у соціальних мережах.

Виклад основного матеріалу дослідження. Дослідження української аудиторії в соціальних мережах, що було проведене компанією GlobalLogic на початку 2021 року, показало що 60\% українців зареєстровані у соціальних мережах [4]. Так, акаунт в Instagram мають 14 мільйонів українців, а у Facebook - 16 мільйонів, що становить 34\% та 39\% від загальної кількості населення відповідно [5]. Важливим моментом у 
просуванні саме медичних товарів у соціальних мережах є дослідження сорер інтересів аудиторії. Більшість користувачів соціальних мереж мають серед своїх підписок такі типи сторінок: інфоромційні (бізнес, сім'я, психологія), розважальні (особисті блоги, фрото та відео контент), шопінг (одяг, дитячі іграшки, побутова та мобільна техніка) і так далі. Оскільки медичні товари не належать до сорери основних інтересів користувачів соціальних мереж, то на такі сторінки підписується невелика кількість аудиторії. У свою чергу така ситуація не може свідчити про те, що виробники товарів особливого призначення не повинні мати сторінку бренду у Facebook чи Instagram. Навпаки, присутність та активність у соціальних мережах дозволяє цільовій аудиторії дізнатись про бренд більшу інорормацію, а фракт присутності вже викликає довіру до бренду та фрормує споживчу лояльність.

Прикладом такої компанії $€$ Biosphere Professional. Напрямок «Biosphere Professional» досить успішно працює 3 2009 року. За двадцять років підприємство засновало портфель різних брендів власного виробництва: «PRO service», «Selpak Professional», «Mercator Medical», «Fantom Professional» (рисунок 1).

Також компанія $є$ офріційним дистриб'ютором бренду «Tork» в Україні. Торгова марка PRO Service - фрлагманський бренд напрямку Biosphere Professional. PRO Service представлений у чотирьох категоріях:

- паперова санітарно-гігієнічна продукція (рушники паперові, туалетний папір, серветки, обладнання);

- матеріали для прибирання (пакети для сміття, серветки для прибирання, рукавички, губки, шкребки);
- спеціалізована хімія (особиста гігієна, засоби для кухні, санвузлів, скла, поверхонь та підлоги, дезінфекція);

- продукція для фрудсервісу (фольга для запікання, пергамент для випічки, харчові контейнери, одноразовий посуд та інше).

В портфелі бренду 246 позицій.

Торгова марка Mercator Medical - брендлідер з виготовлення медичних рукавичок та товарів найвищої якості. В портфелі бренду 10 позицій.

Але для медичних товарів не менш важливим $\epsilon$ саме реклама у соціальних мережах, що буде налаштована на охоплення та залучення цільової аудиторії, її інфрормування про бренд та компанію. Реклама у соціальних мережах, а саме таргетована реклама у Facebook та Instagram дає можливість дуже точно визначити цільову аудиторію та показати рекламне звернення саме їй. Серед налаштувань присутній вибір розташування, віку, статі, мови та детальних інтересів. Приклад налаштування рекламного звернення для медичних товарів зображений на рисунку 2.

Не менш важливо під час налаштування реклами дотримуватись правил та вимог Інтернет-простору. Наприклад, Google забороняє рекламу наступних медичних товарів:

- лікарські засоби, що відпускаються без рецепта лікаря;

- ліки, що відпускаються за рецептом;

- заборонені фармацевтичні препарати та харчові добавки;

- товари та послуги, пов'язані з вагітністю та репродуктивною здатністю;

- товари та послуги для підвищення сексуальної активності.

Обмеження можуть змінюватись в залежності від товарів і послуг, що просуваються, а

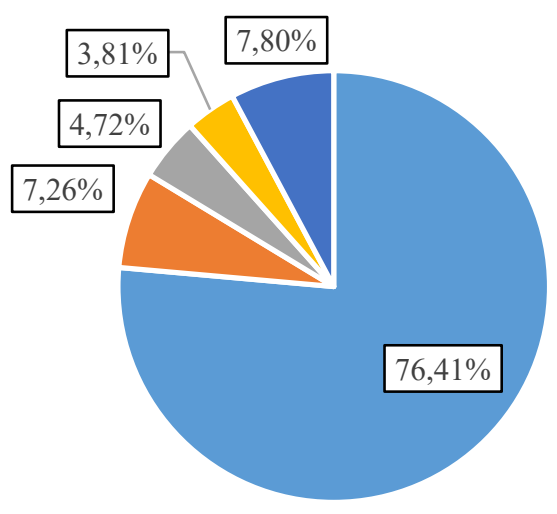

$\square$ PRO service $\square$ Selpak Professional $\backsim$ Mercator Medical $\backsim$ Fantom Professional $\backsim$ Tork

Рис. 1. Структура Biosphere Professional за брендами, 2020 р. 


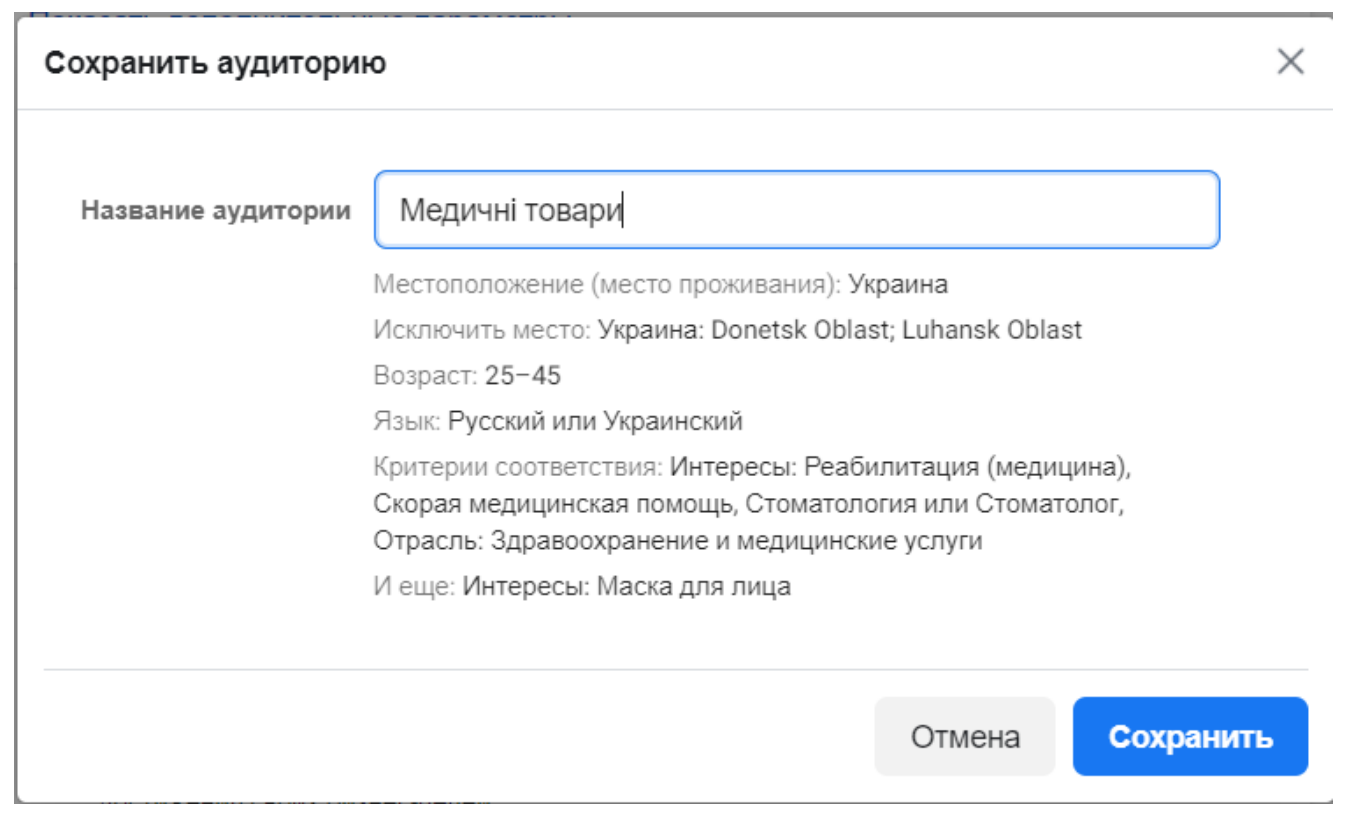

Рис. 2. Налаштування аудиторії в Facebook Ads Manager

Джерело: сформовано авторами

також цільових країн. Реклама фрармацевтичних препаратів заборонена у всіх країнах [7].

щодо реклами у Facebook та Instagram, у даних соціальних мережах тимчасово заборонено рекламу, яка просуває продаж певних медичних та інших товарів з високим попитом, пов'язаних із COVID-19, оскільки така реклама має експлуатаційний характер. До таких товарів відносяться:

- медичні маски для обличчя, у тому числі маски, які використовуються медичними працівниками для захисту від різних захворювань;

- тест-системи для діагностики COVID-19 Товари для самодіагностики (наприклад, без консультації 3 медичним працівником або його призначення);

- подарунки та розіграші таких товарів.

Висновки. Цифрові технології постійно стають доступнішими, що сприяє зростанню кількості користувачів Інтернету та соціальних мереж. Оскільки соціальні медіа стають невід'ємною частиною життя людей, вони також $€$ важливими для зростання та популя- ризації товарів медичного призначення. Особливостями просування товарів медичного призначення, в першу чергу, є певна обмеженість щодо використання інструментів та типу контенту, оскільки дана категорія $€$ специфрічною, а просування у мережі Інтернет регулюється політикою Google. У свою чергу використання соціальних мереж $\epsilon$ одним 3 найбільш перспективних каналів комунікацій. При просування товарів медичного призначення треба враховувати наступні особливості: публікація повинна привернути увагу користувача, бути цікавою та легко засвоюватися.

Компанії-виробники товарів медичного призначення, які підтримують сильну соціальну присутність, отримують перевагу на конкурентному ринку. Коли компанії інвестують у багатоспрямований SMM за участю Linkedln, Facebook, та Instagram, вони зв'язуються 3 потенційними покупцями і водночас дізнаються про конкурентів. Таким чином, регулярне використання стратегії SMM дає вам змогу підтримувати своїх потенційних клієнтів і брати участь у двосторонній взаємодії з ринком.

\section{СПИСОК ВИКОРИСТАНИХ ДЖЕРЕЛ:}

1. O'Reilly T. What is Web 2.0: design patterns and business models for the next generation of software. 2005. URL: https://www.oreilly.com/pub/a/web2/archive/what-is-web-20.html

2. Jurgenson N. The Social Photo: On Photography and Social Media. New York : Verso, 2019. 144 p.

3. Barrett, Meredith A., Humblet, Olivier, Hiatt, Robert A. Big data and disease prevention: From quantified self to quantified communities. Big Data, 2013. 168-75 p.

4. Українська аудиторія соцмереж збільшилася на 7 млн осіб. URL: https://ain.ua/2021/03/17/ukrainskayaauditoriya-socsetej-2021-issledovanie/ 
5. Статистика населення України. URL: https://index.minfin.com.ua/reference/people/

6. Biosphere Professional. URL: https://biosphere-corp.com/ua/direction/tovari-dlya-profesijnogo-vikoristannya/

7. Налаштування Google. URL: https://support.google.com/merchants/answer/6150151?hl=ru

\section{REFERENCES:}

1. O'Reilly T. (2005) What is Web 2.0: design patterns and business models for the next generation of software. Retrieved from: https://www.oreilly.com/pub/a/web2/archive/what-is-web-20.html

2. Jurgenson N. (2019) The Social Photo: On Photography and Social Media. New York: Verso, $144 \mathrm{p.}$

3. Barrett, Meredith A., Humblet, Olivier, Hiatt, Robert A. (2013) Big data and disease prevention: From quantified self to quantified communities. Big Data, 168-75 p.

4. Ukrainska audytoriia sotsmerezh zbilshylasia na $7 \mathrm{mln}$ osib [The Ukrainian audience of social networks has increased by 7 million people]. Retrieved from: https://ain.ua/2021/03/17/ukrainskaya-auditoriya-socsetej-2021-issledovanie/

5. Statystyka naselennia Ukrainy [Statistics of the population of Ukraine]. Retrieved from: https://index.minfin.com.ua/reference/people/

6. Biosphere Professional. Retrieved from: https://biosphere-corp.com/ua/direction/tovari-dlya-profesijnogovikoristannya/

7. Nalashtuvannia Google [Google settings]. Retrieved from: https://support.google.com/merchants/answer/ $6150151 ? \mathrm{hl}=\mathrm{ru}$ 